\title{
МЕНЕДЖМЕНТ ОРГАНІЗАЦІЙ
}

Канд. екон. наук М.В. Найдьонова, К.В. Захарчук

\section{ФОРМУВАННЯ ФАКТОРІВ ОРГАНІЗАЦІЙНОГО РОЗВИТКУ ПІДПРИЕМСТВА В СУЧАСНИХ УМОВАХ ГОСПОДАРЮВАННЯ}

\author{
Представив д-р екон. наук, професор О.Г. Дейнека
}

\begin{abstract}
Постановка проблеми. Вступ людства в епоху «постіндустріального розвитку», або «стадію побудови інформаційного суспільства», явища глобалізації, а також кризові явища у світовій економіці та економіці України ставлять відповідні вимоги до формування планів розвитку підприємств і організацій. Організаційний розвиток на даному етапі має враховувати всі ці тенденції і давати можливість компенсувати їх негативні прояви, i використовувати на благо підприємства надані ними можливості за рахунок оптимального використання внутрішніх можливостей підприємства. Тому актуальним $\epsilon$ вивчення факторів організаційного розвитку підприємства, яке дозволяс вирішити важливе науковопрактичне завдання пошуку резервів розвитку підприємств в умовах глобалізації і реалізувати інноваційну модель розвитку підприємства.
\end{abstract}

Аналіз останніх досліджень i публікацій. Вивченню факторів організаційного розвитку присвятили свої роботи Дж. Пірс і Р. Робінсон, О.В. Віханський, С.I. Некрасов, В.А. Баринов, В.П. Кукоба, B.I. Тоцький та ін.

Причому інтерес до проблеми виявляють як соціологи, так і економісти, менеджери. Так, у роботі Дж. Пірса і Р.Робінсона були виділені групи ключових внутрішніх чинників, які можуть бути джерелами як переваг, так i недоліків підприємства.

O.В. Віханський як фактори організаційного розвитку пропонує глобалізацію ринків, побудову інформаційного суспільства, появу принципово нових організаційних структур, зміну в структурі і якості робочої сили.

У роботі В.П. Кукоби наголошується, що рушійною силою організаційного розвитку $є$ потреба підприємства в перервах. Зміни - питання, що стосується всіх підприємств i компаній. Зміни всередині організації зазвичай відбуваються як реакція на зміни у зовнішньому середовищі. Часто поштовхом до змін $є$ кризові ситуації.

Виділення невирішених частин загальної проблеми. Таким чином, можна виділити такі причини, що породжують потребу в організаційному проектуванні та розвитку, як розукрупнення компанії для підвищення керованості та економічної ефективності; виведення компанії з кризи; реструктуризація компанії як комплекс заходів для його оновлення та підвищення конкурентоспроможності; перепроектування компанії на принципах визначення стану «як має бути».

При всій умовності даної класифікації причини згруповані за умовою розвитку i накопиченого досвіду менеджменту. 
Формування цілей статті. Метою статті $€$ розгляд системи факторів організаційного розвитку підприємств на підставі аналізу літературних джерел та вивчення практики розвитку підприємств.

Виклад основного матеріалу дослідження й обгрунтовування одержаних наукових результатів. Під факторами організаційного розвитку пропонуємо розуміти моменти, суттєві обставини у розвитку підприємства, що дають можливість його якісних змін i зростання життєздатності підприємства.

Фактори організаційного розвитку підприємства можна поділити на дві групи: внутрішні (ендогенні) і зовнішні (екзогенні).

При цьому в кожній групі можна виділити загальні та специфічні фактори. Наприклад, до груп внутрішніх факторів організаційного розвитку можна віднести забезпеченість ресурсами або наявність і якість цілей підприємства, а до специфічних - історію формування капіталу підприємства, наявність неформальних зв'язків 3 інвесторами і 3 органами влади. До загальних зовнішніх факторів можна віднести конкуренцію на внутрішньому ринку країни. Специфіка другої групи факторів буде обумовлена територією, періодом розгляду, галуззю. Безумовно, часто досить складно провести межу між загальними i специфічними факторами організаційного розвитку, більш чітко цей зв'язок може простежуватися тільки в порівнянні 3 іншою територією (країною) або через певну кількість років.

Внутрішнє середовище на відміну від зовнішнього представляє фактори, які підприємство може контролювати, управляти ними.

До внутрішніх факторів організаційного розвитку можна віднести:

1. Керуючі фактори:

- зростання внутрішньої ентропії, що означає таке комплексування ресурсів i використання позитивного ефекту масштабу, при якому витрати на досягнення цільового ефекту будуть мінімальними;

- процес самоорганізації (самонавчання), тобто приведення у відповідність різноманіття управлінських реакцій підприємства 3 різноманіттям впливів і збурень зовнішнього середовища;

- орієнтація на передбачення i прогнозування, тобто проактивне управління. В умовах швидкоплинності зовнішнього середовища одним з важливих факторів успіху в управлінні підприємством стає вміння керівництва прогнозувати і передбачати майбутні зміни і відповідно до цього змінювати стратегію розвитку;

- горизонтальні принципи побудови підприємств, при яких управління будується на базі процесного підходу, i підприємство являє собою плоску ієрархію, зменшуються витрати на вертикальне адміністрування, функціональні завдання підбираються 3 точки зору створення синергічного ефекту при їх виконанні;

- впровадження інформаційних технологій на підприємстві $є$ поштовхом до зміни структури управління, дозволяє зменшити витрати часу i праці на управління та підвищити його якість;

- інновації в управлінні. Наявність інноваційних рішень в управлінні вже $\epsilon$ одним 3 ключових факторів успіху підприємства;

- орієнтація підприємства на додану вартість. У технологічному ланцюжку створення готового продукту підприємство прагне до збільшення доданої вартості;

- синергетика.

В умовах глобалізації світової економіки i зростання невизначеності зовнішнього середовища вміння керівництва досягати синергетичного ефекту як при використанні внутрішніх ресурсів підприємства, так i при використанні зовнішніх можливостей буде запорукою успіху на ринку.

2. Виробничі фактори: забезпеченість ресурсами (технологічними, фінансовими, 
матеріальними, сировинними, енергетичними, майновими, кадровими, інтелектуальними, підприємницькими, інформаційними); інновації у виробництві; виробничо-технічна структура підприємства; рівень технології виробництва.

3. Соціальні фактори: кадровий склад; кадрова політика; соціально-економічна структура; рівень кваліфікація персоналу; готовність персоналу до змін; методи мотивації і стимулювання.

4. Маркетингові фактори: імідж i репутація компанії; номенклатура товарів; якість i життєвий цикл продукту; маркетингові дослідження ринку; канали товаропросування; організація збуту i реклама;

5. Інші фактори: збіг обставин на користь підприємства, форс-мажор, несподівані негативні тенденції в оточенні підприємства задають вектор і стимул для розвитку; вдалий ризик i керування ризиками, як основа підприємництва та розвитку.

Зовнішні фактори організаційного розвитку пропонуємо поділити на три групи: регіональні, макроекономічні, глобальні.

Регіональна політика покликана поліпшити процеси ринкової трансформації господарства за рахунок більш ефективного використання потенціалу регіонів, вдосконалення взаємодії органів державної влади та місцевого самоврядування.

До регіональних факторів організаційного розвитку належать:

1. Наявність програм розвитку на регіональному рівні. Ці програми пропонують такий розвиток підприємств промислового комплексу, який буде направлено на збереження стабілізаційних процесів на підприємствах міста, забезпечення позитивних темпів економічного зростання та подальших якісних змін у структурі виробництва. Для вирішення проблем соціальноекономічного розвитку на період до 2015 року промисловість буде розвиватися 3 урахуванням концептуально визначених пріоритетів технологічної трансформації виробництва:

- послідовна структурно-технологічна та організаційно-економічна модернізація основних виробництв і галузей;

- розвиток високотехнологічних наукоємних i pecyрсо- та енергозберігаючих виробництв і галузей;

- поглиблення спеціалізації промислових підприємств; диверсифікація застарілих виробництв, розширення виробничої кооперації; формування сучасного високотехнологічного та збалансованого машинобудівного комплексу;

- поступове скорочення технологічно застарілих, економічно небезпечних i економічно неефективних, ресурсо-та енергоємних виробництв;

- цілеспрямований

розвиток виробництв експортної та імпортозамінної продукції, посилення зовнішньоекономічної орієнтації промисловості міста;

- розвиток науково-технічних та дослідно-конструкторських розробок, посилення інноваційної орієнтації промислового виробництва;

- посилення соціальної орієнтації промислового виробництва, випереджаюче зростання виробництва товарів народного споживання; освоєння випуску сучасних видів споживчих товарів;

- підтримка і стимулювання вітчизняного товаровиробника; сприяння розвитку підприємництва у виробничій cфepi;

- створення нових робочих місць.

2. Зростання споживчих вимог. Існуюча в даний момент криза перевиробництва диктує нові вимоги до споживаної продукції, послуг. Серед основних 3 них можна виділити поліпшення якісних характеристик, зростання функціональних можливостей, зручність в експлуатації.

3. Зростання конкуренції на внутрішньому ринку. Формування ринкового середовища економіки України 
супроводжується зростанням конкуренції на внутрішньому ринку, що обумовлено збільшенням кількості конкурентів і посиленням позицій вже існуючих, появою лідерів ринку.

4. Постачальники. Пропозиція нових видів сировини і матеріалів стимулює підприємства до освоєння нової продукції i, як наслідок, до організаційних змін.

5. Акціонери та інші зацікавлені групи. Підприємство функціонує як «відкрита» організація, зацікавлена в досягненні не тільки внутрішніх цілей. Істотна увага має приділятися не тільки своїм акціонерам, а й інтересам інвесторів і партнерів, які мають значну вагу в корпоративному управлінні.

6. Екологія регіону.

7. Громадські інститути - державні органи, громадські організації, політичні партії та рухи, профспілки; ринок трудових ресурсів.

До макроекономічних факторів організаційного розвитку підприємства можна віднести такі:

1. Програми розвитку промисловості на державному рівні. Модернізація та підвищення конкурентоспроможності промислового виробництва вимагає оновлення організаційного устрою галузі 3 урахуванням світових тенденцій формування організаційних структур та власного досвіду ринкових перетворень.

Найбільш актуальними шляхами удосконалення організаційного устрою промислового комплексу $\epsilon$ капіталізація, вертикальна i горизонтальна інтеграція підприємств, розвиток корпоративного сектора; здійснення процесів концентрації промислового виробництва на засадах підвищення конкурентноспроможності і недопущення суттєвих обмежень конкуренції чи монополізації; розроблення та впровадження моделі кластерної організації промисловості в межах територіального устрою.

2. Енергозберігаюча модель розвитку економіки. Особливістю і пріоритетом промислової стратегії на сучасному етапі стає важливе зменшення енергоємності виробництва, надійне забезпечення платоспроможних потреб в енергетичних ресурсах, зміцнення енергетичної незалежності України.

3. Інноваційна модель розвитку України. На сучасному етапі суспільного розвитку основною рушійною силою економічного прогресу $\epsilon$ інновації, a конкурентна позиція України на світовій арені визначається іiі інноваційним потенціалом та інноваційною активністю i створює умови для розвитку бізнесу.

4. Екологія країни

5. Можливості в економіці, що розвивається. Перехід від планової економіки до ринкової призвів до зміни галузевих пріоритетів, зміни критеріїв господарювання i дав змогу низці підприємств посісти лідируючі позиції на ринку.

Аналізуючи соціальну компоненту макрооточення підприємства, розглядають населення (рівень добробуту, звичаї, вірування, цінності, професійно-освітню, демографічну структуру).

6. Розшарування населення. Низька частка середнього класу створює деякий потенціал для розвитку бізнесу в разі формування умов для його збільшення.

7. Політична та економічна нестабільність. У контексті даної роботи політична та економічна нестабільність може розглядатися як фактор стимулювання ділової активності, як спосіб самостійного вирішення проблем розвитку підприємства.

8. Урбанізація населення. Приплив населення 3 невеликих населених пунктів у великі міста, обумовлений пошуком більш високого рівня життя, дає таку можливість підприємству, як розширення діяльності за рахунок відкриття відділень і філій, нових виробництв, розвиток сфери послуг.

До глобальних факторів можна віднести: 
1. Власне процес глобалізації, який привів до економічного зростання, більш високої продуктивності, розповсюдження передових технологій, скорочення масштабів міжнародних конфліктів i посилення міжнародної координації.

2. Курс на євроінтеграцію

3. Урахування національних культур в управлінні.

4. Глобальні інформаційні системи.

5. Глобалізація банківської системи.

6. Глобальна конкуренція.

7. НТП, розвиток технології.

8. Інформаційне суспільство передбачає створення глобального інформаційного простору, збільшення ролі інформації i знань, зміна характеру трудової діяльності.

9. Економіка знань, яка посяде лідируючі позиції у XXI столітті завдяки своєму головному суб'єкту - творчій людині.
10. Світова економічна криза дає можливість переосмислення існуючого положення справ, зміни структури економіки і розвитку окремих сфер бізнесу.

Висновки даного дослідження i перспективи подальших робіт у вказаному напрямі. Організаційна структура управління на підприємствах відіграє надзвичайно важливу роль. Усі великі підприємства пройшли певні етапи розвитку організаційних структур. Побудувавши спочатку свої структури управління за проектним принципом, використовуючи неформальні організаційні структури, надалі в міру зростання підприємства змушені переходити до використання ієрархічних принципів, які можна охарактеризувати як більш низький рівень розвитку організаційних структур. Не існує однозначно гарних чи поганих структур управління, можуть бути різні умови їхнього застосування.

\section{Список літератури}

1. Галицький, В.П. Забезпечення ефективної діяльності організації [Текст] / В.П. Галицький. - К., 2002.

2. Некрасов, С.И. Факторы организационного развития [Текст] / С.И. Некрасов, Н.А. Некрасова, О.В. Бусыгин. - М.: Изд-во "Академия Естествознания", 2009.

3. Штомпка, П. Социология социальных изменений [Текст] / П. Штомпка. - М., 1996.

4. Тоцький, В.I. Організаційний розвиток підприємства [Текст]: навч. посібник / В.І. Тоцький, В.В. Лаврененко. - К.: КНЕУ, 2005.

5. Кукоба, В.П. Організаційне проектування підприємств [Текст]: монографія / В.П. Кукоба. - К.:КНЕУ, 2009.

6. Баринов, В.А. Организационное проектирование [Текст] / В.А. Баринов. - М.: ИНФРА-М, 2005.

Ключові слова: організаційний розвиток, внутрішні і зовнішні фактори організаційного розвитку, глобалізація.

\section{Анотаціï}

Проаналізовано поняття факторів організаційного розвитку підприємства. Розглянуто класифікацію факторів організаційного розвитку та систему зовнішніх і внутрішніх факторів організаційного розвитку підприємства. 
Проанализировано понятие факторов организационного развития предприятия. Рассмотрена классификация факторов организационного развития и система внешних и внутренних факторов организационного развития предприятия.

The article analyzes the concept of organizational factors of the enterprise. The classification of the factors of organizational development and system of external and internal factors of organizational development company. 